\title{
THE GEOLOGIC AND STRUCTURAL RELATIONS AT SANTA RITA (CHINO), NEW MEXICO. ${ }^{1}$
}

\author{
Sidney Paige.
}

The following paper will present briefly the major geologic and structural features observed in the Santa Rita region while the writer was engaged in preparing a geologic map of the Silver City Quadrangle during the summer of I9I0. The area about Santa Rita was not given such attention as it would naturally receive in the course of an exhaustive study for a monographic publication. Nevertheless, in the preparation of a geologic map on a scale of 2 miles to the inch (approximately) the major relations were of necessity determined. It is because of certain misapprehensions which have arisen regarding this interesting and economically important area that the following paper is presented. That the views herein expressed do not wholly agree with what has already been published ${ }^{2}$ rests solely upon the fact that the writer was afforded more ample opportunities to pursue the investigation.

It is of interest to state briefly the views of $\mathrm{Mr}$. Graton (to whom fell the lot of examining this area) as well as those of a number of other observers. Mr. Graton says:

"The most conspicuous quartzite is found in the heart of the developed area in the Santa Rita camp and immediately to west and south. What is regarded as the same quartzite is present in places along the west side of Hanover Creek and in the Hanover mine and is said to extend on the surface for some distance farther northwest, though this statement was not verified. The rock is rather fine grained, gritty, decidedly cemented by silica, and commonly almost white, though in places it is almost black owing to the presence of black iron ore in small grains.

${ }^{2}$ Published with the permission of the Director of the United States Geological Survey.

${ }^{2}$ Lindgren, Graton and Gordon, "Ore Deposits of New Mexico," Prof. Paper, U. S. Geol. Survey, No. 68, I9Io. 
The quartzite probably has a thickness of at least 200 feet; it occurs on the surface at the Romero mine and is present in a crosscut from the Santa Rita shaft 200 feet below; the intervening ground is inaccessible and it is not certain that the quartzite extends throughout that distance, as irregular intrusions of porphyry are numerous in the vicinity. The bottom of the quartzite is somewhere above the 300 -foot level, for the rock is not seen at that depth. The quartzite along Hanover Creek underlies and apparently belongs at a lower horizon than the limestone; the quartzite at Romero Hill is believed to occupy a similar stratigraphic position and in the absence of any other known quartzite below the Carboniferous is regarded probably as Cambrian and the equivalent of the thick quartzite series at the base of the Silver City section, I5 miles to the west. This view is strengthened by the similar character of these rocks in the two regions.

"Near the Ivanhoe mine, in the southwest corner of the area, quartzite is found close to the limestone already mentioned as probably Mississippian, and though the actual relations of the two were not ascertained, it is believed that the quartzite overlies the limestone. Much of this quartzite is gray, of finer grain and less cemented by silica than the quartzite previously described; it is conglomeratic and cherty in places like that occurring between the Carboniferous and the Cretaceous in the Silver City section. Quartzite believed to be related to this occurs on the Pedro claim on the hill east of the Santa Rita basin. A small thickness of quartzite is said to cap the high mesa east of and overlooking Hanover Creek, and quartzite has been reported recently from the hills west of Hanover Creek and below the town of Hanover. These four occurrences of quartzite are considered by the writer as presumably parts of one formation, which is to be regarded as of later age than the quartzite exposed in and around the principal Santa Rita mines and in the Hanover mine. Whether or not this younger quartzite formation belongs at the horizon of the similar material which is found at Pinos Altos, Silver City, Bear Mountain, and Telegraph, and which in the Silver City section occurs between the Pennsylvanian and the Cretaceous, cannot be definitely stated, but such a position for it seems probable. This view is not in accord with those contained in private reports on the region made both before and after the present writer's visit to this district, and it must be admitted that the conclusions as to stratigraphic sequence here set forth are not regarded as thoroughly established. Further consideration will be given to this question on pages 309-3II."

"Schist was found at only two places-the Santa Rita mine in the center of the Santa Rita camp and the Modoc tunnel, near the north 
end of the Hanover district. The rock is very fine grained and either very dark brown or dark green, and where fresh shows the glistening surface of minute biotite flakes. Stringers and accretions of magnetite are common. At places in the Santa Rita mass are numberless tiny stringers of quartz. The microscope reveals the usual mosaic texture of the crystalline schists. Biotite is most abundant, followed by quartz and a feldspar that is not certainly determinable, but appears from its refractive index to be orthoclase. Magnetite, apatite, and zircon are present as accessories. Alteration produces serpentine abundantly, giving the rock a yellowish-green color, and as much of the rock exposed is somewhat altered it has received the local name 'greenstone.' The rock in the Santa Rita workings is similar to but a little coarser than that in the Modoc tunnel, and contains more magnetite. The supposition entertained at the time of its collection, that it might possibly be shale much metamorphosed by the near-by porphyry, was disposed of when microscopic study could be made. The rock is plainly the result of deep-seated regional metamorphism and is almost certainly preCambrian. At both places the schist appears to occur as irregular bodies surrounded by the porphyry, as if torn from the parent mass and carried off in the porphyry melt. The mass in the Santa Rita mine is encountered on the 300 -foot level and is at least several hundred feet in diameter. It is present under the quartzite found on the 200-foot level and is probably to be regarded as the Pre-Cambrian basement on which the sediments were deposited. The mass in the Modoc tunnel is more clearly a detached piece; so far as exposed it was surrounded by quartz monzonite porphyry and its relation to the limestone, which outcrops on the hill above, was not ascertained.

"Many of the facts regarding the structure and the attitude of the rocks have already been implied, and the question regarding sequence has been mentioned. The view that the quartzite found at the Santa Rita mines and at the Hanover mine lies below the limestones and is of Cambrian age is supported by the similarity of the rock to the known Cambrian quartzite west of Silver City and by the presence, probably immediately underlying it, of schist that must be regarded as preCambrian. The conclusion that the limestone formerly overlay the orebearing rocks at Santa Rita had already been reached by S. F. Emmons. He says: "The ore is found in a white quartz porphyry, ${ }^{2}$ which was evidently once covered by horizontally bedded limestones, that still lie round the rim of the shallow basin where it occurs.'

${ }^{1}$ Genesis of Ore Deposits, Special Vol. T. A. I. M. E., New York, I902, pp. 449-450.

${ }^{2}$ The quartzite was apparently not separated from the altered porphyry that invades it promiscuously. 
"Since I905, when the region was visited a considerable amount of private geologic work has been done in the Santa Rita camp; the results of a part of these investigations have been published, ${ }^{1}$ and recently the writer has been shown a private geologic report on the Santa Rita district made for the Santa Rita Mining Company in 1899. In both of these reports it is assumed that only one quartzite horizon is present in the region and that the quartzite in the heart of the Santa Rita camp is a down-faulted block. This view has been clearly presented in the older report, in which the opinion is expressed that the Carboniferous limestones underlie the whole Santa Rita property and that the quartzite lies above the limestones, separated from them by $I_{50}$ to 280 feet of 'iron formation.' Concerning the relations of the limestone and quartzite in the heart of the Santa Rita camp the report says: 'The change from the ... limestone country on the north and east to the more diversified geology of Santa Rita [quartzite, "iron formation," porphyries, and rhyolite] takes place abruptly along a ragged line. ... Along this line in various places both the iron formation and the quartzites are brought into lateral juxtaposition with the limestones under such circumstances that their present relations can be explained only by supposing that the rocks south of this line have dropped, relatively to to main limestone block, to the extent of from 400 to 600 feet.' This reference to views not according with his own is made by the present writer because he feels that his own observations were not sufficiently detailed and extensive to establish his deductions conclusively, and it seems only fair to present all aspects of the question. The actual discovery and exact location of lines of faulting appear not to be mentioned in either of the private reports referred to, and, in both, the evidence of faulting seems to rest mainly on the assumption that the limestone is the lowest member of the column. Extending from the Kneeling Nun in a direction slightly west of north is a comparatively steep, serrated slope that forms the western boundary of the limestone mesa. This slope is to be regarded not as a fault scrap modified by erosion, but as the steep side of an anticlinal valley (Hanover Creek) formed by erosion of the elongated dome resulting from the intrusion of the quartz monzonite porphyry. The opposite or west wall of this valley is of gentler slope, but plainly exposes the same rocks forming the other limb of the anticline. This anticlinal structure is unmistakably evident through almost the entire length of the Hanover Valley. Santa Rita Creek has cut back into this steep east well and formed a depression or pass, through which leads the road to Georgetown. The limestone recedes up Santa Rita Valley, exposing quartzite (and porphyry), the boundary line of the limestone tending to conform with the

${ }^{1}$ Sully, John M., Report on the property of the Santa Rita Mining Company, Boston, I909. 
valley contours and the dip being away from the quartzite. It is evidently this situation that Emmons refers to when he says ${ }^{1}$ that the limestones 'lie around the iron of the shallow basin.' This embayment in the limestone and the corresponding tongue of quartzite occupying the depression caused by Santa Rita Creek afford, perhaps, the best evidence in favor of the higher stratigraphic position of the limestone relative to the quartzite. The complicating feature of the 'iron formation' in the private report referred to is now, of course, explained as the zone of contact-metamorphosed limestone, a type of deposit whose nature ten years ago was seldom recognized and poorly understood.

"It seems probable, therefore, that the quartzite in the central part of the Santa Rita camp underlies the limestone. Nevertheless, the position in which it is found requires some explanation. If the quartzite is Cambrian, as seems probable, it lies of course at the base of the sedimentary series. But the full series is not present in the Santa Rita and Hanover districts, as is shown by sections at Georgetown, Lone Mountain and Silver City, nor is the quartzite present consistently between the limestone and the porphyry. The explanation of the presence of Cambrian and pre-Cambrian rocks in the Santa Rita camp and in the vicinity of the Hanover and Modoc mines in the Hanover district is believed to be that masses of these rocks have been torn off by the quartz monzonite porphyry magma and forced with it up through part of the overlying sediments to the abnormal stratigraphic position they now occupy. It may be that some of the lower limestones have likewise been brought up to a higher level and, being close to the magma, have been metamorphosed too much for determination. It may thus be that some of the shale exposed is from the underlying Devonian. If, therefore, as has been asserted by others, faults surround or bound this Cambrian quartzite mass, together with the pre-Cambrian schists and any older Paleozoic rocks that may have been forced up with it, the quartzite and adjacent rocks have probably been relatively raised rather than depressed along such faults."

The present writer is of the opinion that a much simpler explanation for the structure at Santa Rita is at hand.

To understand clearly the geology at Santa Rita and to appreciate readily the force of the relations there observed, it is necessary to have a clear conception of the geologic units which compose the larger area of which Santa Rita is but a small part. The simple but obscured relations within that basin will then become apparent.

${ }^{1}$ Emmons, S. F., The Secondary Enrichment of Ore Deposits. Special Vol. T. A. I. M. E., Genesis of Ore Deposits, p. 449. 
Upon a basement of Pre-Cambrian granites (containing poorly defined inclusions of quartzite and schists), there has been deposited a series of sedimentary rocks comprising Upper Cambrian sandstones, Ordovician limestone, Silurian limestone, Devonian shale, Carboniferous limestone, Cretaceous quartzite, and Cretaceous shale with sandy layers. Upon this series of rocks, but following a prolonged period of erosion, Tertiary lavas have been poured out during successive eruptions between which, however, there accumulated considerable deposits of tuff and tuffaceous sands. Quaternary sedimentary deposits with interbedded basaltic flows have added their quota to this imposing succession.

Within this series two unconformities (there are more) are important. First that marked by the erosion interval preceding the deposition of basal Cretaceous quartzite and second, that marked by the erosion preceding the extravasation of the Tertiary lavas. Both of these unconformities are present at Santa Rita.

Intrusion, folding, and pronounced faulting have combined to disturb the original orderly sequence of this stratified series.

In addition to the late flows of lava already mentioned, a number of distinct periods of igneous intrusions have prevailed. First, the intrusion into (and perhaps extravasation upon) Cretaceous rocks of a complex of generally dark-colored porphyritic rocks of dioritic and andesitic facies associated with what appear to be volcanic breccias (and lavas) of a similar type; second, the intrusion of quartz diorite porphyry as laccoliths and stocks; third, the intrusion of holocrystalline masses of quartz-monzonitic, dioritic, and granitic rocks with associated porphyritic facies and accompanying dikes. These rocks cooled more slowly than their predecessors and solidified (at least the portions now exposed by erosion) before reaching the surface of the earth; fourth (and these followed the lavas already mentioned in the stratigraphic columns), the intrusion of stocklike masses comprising rhyolitic and latitic facies of fine-grained porphyries breaking through all the older rocks and through the lavas as well. Igneous activity was closed by the eruption of the late basaltic 
lavas already mentioned in connection with the Quaternary gravels.

The earliest folding which has been recognized probably accompanied the intrusion of the holocrystalline dioritic and granodioritic masses. Such an assumption is based partly on the laccolithic nature of these intrusions and partly on physiographic evidence which need not be presented here. The earliest faulting that can be recognized followed the extravasation of the Tertiary andesitic and rhyolitic lavas, and its effect upon the configuration of the surface was far reaching. To it is due the monoclinal basin-range structure of several of the mountain masses of the area, and likewise the accumulation of deep and widespread deposits of Quaternary gravel. This faulting initiated perhaps in late Tertiary time has continued intermittently down to a very recent date.

This history of rather notable dynamic disturbance was accompanied by stages of important mineralization. But though it is not desirable to present at this time a classification of the several types of ore bodies which have resulted, a table is appended which epitomizes those geologic events which are important with respect to ore formation; and at the same time indicates the stage occupied by the deposits at Santa Rita.

THE STRUCTURAL AND GEOLOGIC RELATIONS AT SANTA RITA.

The geologic and structural relations at Santa Rita are more easily understood and more concisely correlated with the general geology of the region if an area of considerably wider extent than that of Santa Rita basin is described. Such an area is comprised in the geologic map shown in (Fig. 70).

Two factors have contrived to obscure the geologic relations at Santa Rita. First, the intense metamorphism connected with the intrusion of quartz monzonite porphyry (granodiorite); and second, faulting. The first factor is peculiarly accentuated because of the lithologic similarity of the rocks which it effects.

Presented in the order of their occurrence the later geologic events recorded by surface relations to this area are: 


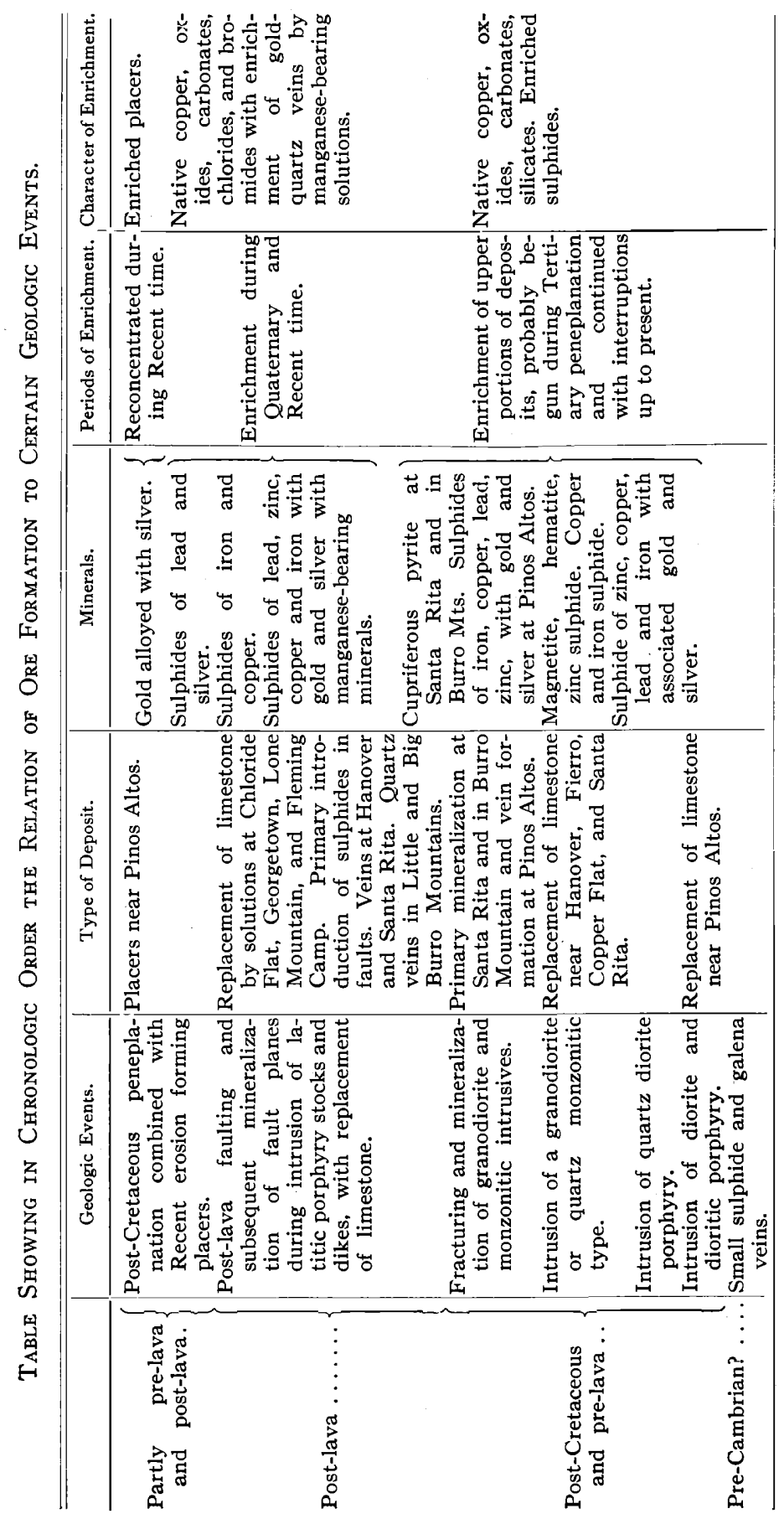



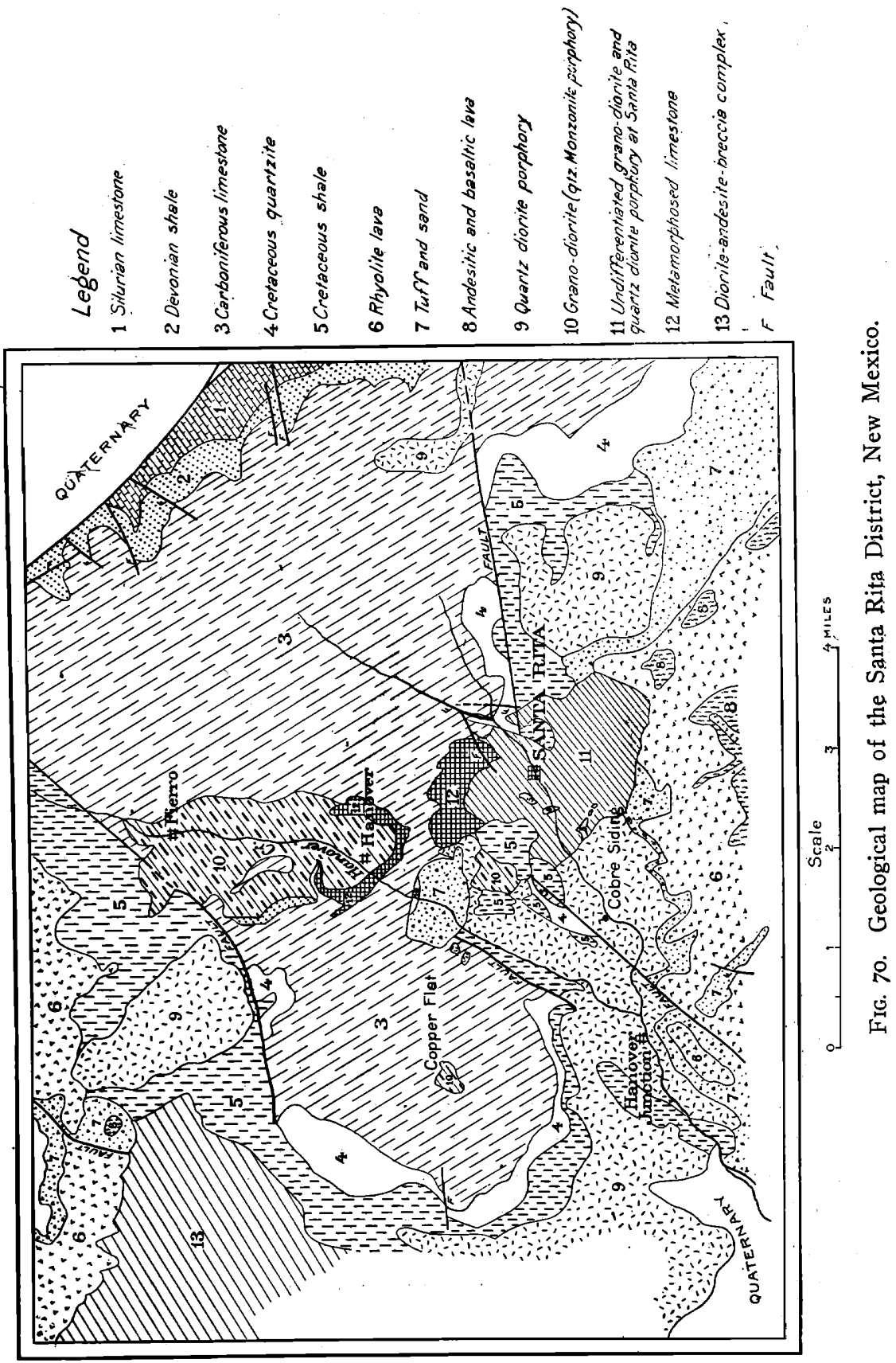
I. The intrusion of quartz diorite porphyry laccoliths and stocks (see map, Fig. 70).

2. The later intrusion of quartz monzonite porphyry or granodiorite porphyry likewise taking a laccolithic form (the anticlinal structure in the Hanover-Ferro basin and the quaquaversal dips at Copper Flat suggest this relation). The central mass at Santa Rita is this type of porphyry though not separated on the map from the quartz diorite porphyry within the oxidized area, for reasons to be set forth below. These late granodiorite intrusions were accompanied by intense contact metamorphism, with all the usual results of such metamorphism where calcareous and argillaceous strata are involved. Of special structural interest in the present instance, however, is the metamorphism of the Cretaceous shale and sandy layers. These rocks have been altered to a resistant quartzite-like rock of generally light yellowish color intensely fractured and seamed with siliceous and limonitic veins. The metamorphism produced is probably as much the effect of later solutions following the intrusion of the porphyry as any immediate contact effect. Under the microscope the rock is seen to be made up of an even-grained aggregate of quartz and sericite specked with iron oxide. Epidote is fairly abundant. The present condition of the rock may be ascribed largely to that period of alteration which was accompanied by the primary introduction of pyrite. This rock breaks usually with a decidedly blocky fracture and may be distinguished from the porphyry which intrudes it by the lack of quartz phenocrysts which in the intrusive rock, even where most intensely altered, are always present. It may generally be distinguished from the basal Cretaceous quartzite by its fine-grain, yellow color and blocky cleavage.

The changes produced in the intrusive rocks of the region are also largely those resulting from solutions following very closely (probably) the cooling of the mass and taking advantage of numberless fractures in the rock produced by stresses whose cause remains undetermined.

As interpreted at present the older intrusive rock, the quartz 
diorite porphyry, has been very severely metamorphosed by the after effects of the quartz monzonite porphyry intrusion. The prominent iron-stained hills which lie east, south, and west of the central core at Santa Rita are believed to be this altered quartz diorite porphyry or a quartzose phase of the same. Countless seams and cracks traverse this rock. Great quantities of secondary silica entered in numberless veinlets and the generally oxidized red appearance of the hills speaks of the original pyritization which took place. This rock is generally light in color, stained with iron oxide and intensely fractured and silicified. Quartz phenocrysts may usually be seen while the feldspars are changed to a dull white or dirty color. Under the microscope may be seen large resorbed phenocrysts of quartz, generally abundant, with completely sericitized and epidotized feldspars in a groundmass of quartz and sericitized feldspar. The ferromagnesian minerals have entirely disappeared. Not only are these rocks sericitized, but kaolinization is in places a very prominent alteration. Phenocrysts composed of nearly clear colorless kaolin may be seen under the microscope. With it very abundant secondary amorphous silica may be seen.

The quartz monzonite porphyry, the rock which by drilling has proved to be an important carrier of disseminated copper, is also much altered. The changes which have taken place in it are those which accompanied first the pyritization and later the oxidation of the rock. Abundant sericite has formed in the feldspars; biotite is chloritized, and kaolin is present. Sulphides are especially conspicuous. The rock is much seamed and fractured, but has not received the enormous accessions of secondary silica which seem to have made the surrounding hills of quartz diorite porphyry so resistant.

3. The alteration and mineralization which has just been described, affecting as it did the intruding as well as the intruded rocks, preceded Tertiary peneplanation. This fact is obvious when the position of the Tertiary lavas and tuffs (south of Santa Rita) are considered. These rocks rest upon an eroded surface. The intrusive rocks had already been stripped of their sedimen- 
tary cover and been exposed to oxidizing conditions before this accumulation of lavas took place; meteoric waters had already initiated, and probably carried to a high degree, processes of secondary enrichment when the floods of lava suddenly and effectively brought such enrichment to a standstill.

4. Initiated by forces which have been active throughout the entire Rocky Mountain system there followed a period of severe faulting, the surface was broken into numerous fault blocks; porphyry intrusions accompanied the disturbance. A prolonged erosion interval stripped the lavas from the Santa Rita area. Two faults of this period are prominent in the vicinity of Santa Rita. One enters the district from the south, has a northeast southwest trend, a downthrow to the east, and passes a little west of Cobre Siding. The throw of this fault is elegantly expressed in the lavas southeast of Hanover Junction. The second fault enters Santa Rita from the east, has a nearly east and west trend, a downthrow to the south, and may be readily followed by the discordant structure produced between basal Cretaceous quartzite and Carboniferous limestone. The result of these two breaks is to make of Santa Rita a downthrown block and it is at once obvious that within the bounds of these two faults, the surface rocks are either Cretaceous shale (with interbedded sandstone lentils) or intrusive porphyries. Field observations bear out this interpretatipn. No rock was seen at the surface which could not be assigned either to a silicified phase of shale or sandstone lentil or to an altered phase of either granodiorite or quartz diorite porphyry.

We have in this basin therefore conditions peculiarly combined: to create confusion if the two above described faults are not recognized. The silicified shale and sandstone closely resembles the basal Cretaceous quartzite found on the upthrow side of both faults and on the mountain top to the north, while the alteration of the intrusive rocks has made it impossible (without further detailed study) to delineate the boundary between granodiorite porphyry and quartz diorite porphyry within the silicified area. The writer holds the opinion provisionally (as stated above) 
that this boundary is close to the base of the oxidized red hills east of the bed of Santa Rita Creek, the oxidized red hills being held to be in the main a greatly altered phase of the quartz diorite porphyry.

To epitomize the facts which it has been the purpose of this paper to present, it may be said that the area about Santa Rita is a downthrow fault block within which at the surface are exposed the highly silicified remnants of Cretaceous shales and sandstones intruded by at least two types of porphyry: first, quartz diorite porphyry, and second, quartz monzonite. A correlation of the silicified cretaceous shales with basal Cambrian quartzites is not borne out by the writer's observations. The quartz diorite porphyry is intensely altered and difficult to distinguish from the quartz monzonite porphyry.

The intrusion of the quartz monzonite porphyry was followed by fracturing and pyritization, not only of the intruding porphyry, but of the intruded shales and standstones and the quartz diorite porphyry as well. The first period of secondary enrichment began during a stage of pre-lava peneplanation but was interrupted by a covering of lava sheets. Faulting and the accelerated erosion initiated thereby again caused the porphyries to be exposed and processes of enrichment proceeded down to the present time. The faulting by bringing into juxtaposition metamorphosed shales (with sandy layers) and basal Cretaceous quartzites, contrived to conceal faults which otherwise might have been more readily recognized. The major portion of the ore body, as developed by drills at the time of the writer's visit, was disposed as a great ring surrounding a cove of quartz monzonite porphry. That the ore body may extend also into the fractured surrounding rocks is probable. 